\title{
Thermo-kinematic evolution of the Taiwan oblique-collision mountain belt as revealed by zircon fission track dating
}

\author{
Tsung-Kwei Liu*, Sherry Hsieh, Yue-Gau Chen, Wen-Shan Chen \\ Department of Geosciences, National Taiwan University, 245 Choushan Road, Taipei 10617, Taiwan, ROC
}

Received 4 April 2000; accepted 3 January 2001

\begin{abstract}
Based on analyses of about 970 zircon grain fission-track (FT) ages from 44 clastic rock samples collected from six transects and two pooled ages of apatite concentrates separated from a diabase body, the thermo-kinematic evolution of the Taiwan mountain belt since the last orogenic phase (the Penglai Orogeny) has been delineated for the first time. As a consequence of the active Penglai Orogeny since late Tertiary times, pre-orogenic FTs in detrital zircons and apatites have been subjected to varying degrees of annealing by geothermal heating. The spatial boundary between the partial and complete resetting of zircons coincides well with that corresponding to the $260^{\circ} \mathrm{C}$ isotherm between the greenschist facies and prehnite-pumpellite facies defined previously by crystallinity of potassic micas. The age distribution along each cross-section exhibits younger ages from the mountain front toward the rear plate boundary between the Eurasian and the Philippine Sea plates, suggesting asymmetric cooling and exhumation. Along the strike direction (roughly north to south) of the regional structure, the age distribution reflects southward propagation of the arc-continent collision and subsequent uplift-and-denudation. Spatially, the width of the zircon complete-reset zone gradually narrows down along the strike of the regional structure, reflecting the southward propagation of the arccontinent collision and subsequent uplift-and-denudation. Temporally, zircon FT ages for the western margin of the completely reset zone are progressively younger from 5-6 Ma in the northern part to ca. $2 \mathrm{Ma}$ in the south-central part, then resume to ca. $6 \mathrm{Ma}$ for the southern end, where collision is only in its initial stage. The previously tectonized preTertiary Peikang Basement High on the Asian continental margin plays an important role in defining the uplift-andcooling history and shaping the major salient-and-recess structure and neotectonics of the mountain belt. (C) 2001 Elsevier Science B.V. All rights reserved.
\end{abstract}

Keywords: P-T-t paths; cooling; plate collision; fission-track dating; Taiwan

\section{Introduction}

It is well known that fission-track (FT) 'clocks' can be reset through annealing of fission-damaged

\footnotetext{
* Correspondence author. Tel. and Fax: +886-2-2365-7380; E-mail: liutk@ccms.ntu.edu.tw
}

tracks due to thermal effect, and that the amount of annealing is dominantly temperature- and timedependent (e.g., $[1,2])$. Thus the information provided by the FT method, especially the singlegrain age distribution obtained by the so-called grain-by-grain method, is very useful in studying the provenance of sedimentary rocks (e.g., [3-5]) and the thermal patterns/histories of regions that have undergone tectonism (e.g., [6-9]). 
The mountain belt of Taiwan is one of the best examples in the world of active arc-continent collision. The mountain building processes have been modeled mainly based on structural and sedimentary analyses [10-16], and the thermal histories of parts of the region have also been investigated [17-20]. With the northwestward movement of the Philippine Sea Plate, the north-south trending Luzon Arc on the west margin of the Philippine Sea Plate has been obliquely colliding with and thrusting on the northeast-southwest trending Eurasian continental margin since the late Tertiary, resulting in a number of southeast-dipping imbricate thrust faults and folds (the Penglai Orogeny; Fig. 1). The Longitudinal Valley marks a portion of the suture between the two plates. To the west is primarily the Central Range consisting of pre-Tertiary basement rocks (the Tananao Schist), which experienced its first metamorphism in amphibolite facies at ca. $90 \mathrm{Ma}$, and a thick sequence of Cenozoic clastic sediments that were derived from pre-Tertiary granitic rocks in southeast China. During the Penglai Orogeny, the basement rocks and overlying sediments were metamorphosed, with metamorphic grade decreasing progressively westward from the upper greenschist facies, through prehnite-pumpellite facies in the Slate Formation, to unmetamorphosed sediments in the Western Foothills Belt. The lithostratigraphic units and the metamorphic isogrades are generally aligned parallel to the plate suture [21,23].

Previous FT studies [17,18] on the Tananao Schist have shown completely reset apatite ages ranging from 0.3 to $0.6 \mathrm{Ma}$ and zircon ages from 0.9 to $2.0 \mathrm{Ma}$. Assuming a constant cooling rate within the range of $100-1^{\circ} \mathrm{C} / \mathrm{Myr}$, their effective track retention temperatures were previously estimated at $135 \pm 20^{\circ} \mathrm{C}$ (apatite) and $235 \pm 20^{\circ} \mathrm{C}$ (zircon) as inferred from laboratory track-annealing studies (e.g., [24]). The resulting average cooling rate of the northern Tananao Schist was $\sim 110-220^{\circ} \mathrm{C} / \mathrm{Myr}$ for the last $2 \mathrm{Ma}$. On the other hand, the FTs in the zircons separated from the submetamorphosed Paleogene sandstones of the Hsueshan Range have undergone varying degrees of annealing during the Penglai Orogeny as identified by distribution patterns of grain ages rela- tive to their respective stratigraphic ages [18]. The zircon cooling ages obtained for the completely reset samples from the western part of the Hsueshan Range fall in the range of 4-5 Ma, implying much lower cooling $\left(\sim 50^{\circ} \mathrm{C} / \mathrm{Myr}\right)$ and uplift $(\sim 1.7 \mathrm{~mm} / \mathrm{yr})$ rates than those for the Central Range, the structural core of the orogen.

The main purposes of this paper are: (1) to present the most extensive and systematic zircon FT dating results from Taiwan; (2) to delineate the spatial patterns of the cooling ages and deduce their tectonic implications; and (3) to define the thermo-kinematic evolution of the mountain belt as a whole since the Penglai Orogeny. The EPSL Online Background Dataset ${ }^{1}$ contains background material related to this article.

\section{Samples and experimental methods}

A total of 972 zircon grain ages were obtained from 45 sandstone samples collected from six transects almost perpendicular to the plate suture (the Longitudinal Valley; Fig. 1). Zircons were separated in the usual way, mounted parallel to their $c$-axis in PFA teflon sheets and etched with eutectic mixtures of $\mathrm{NaOH}, \mathrm{KOH}$, and $\left.\mathrm{LiOH} \cdot \mathrm{H}_{2} \mathrm{O}\right)(6: 14: 1 \mathrm{~mol} \%)$ [2] for periods varying from 4 to $40 \mathrm{~h}$ at $210 \pm 4^{\circ} \mathrm{C}$. 'Grain-by-grain' and mica external detector techniques were adopted to obtain individual grain ages. Spontaneous tracks were etched on external prismatic surfaces of euhedral grains (i.e., $2 \pi$ geometry) [25]. Track counting was conducted using a magnification of $2500 \times$ under oil immersion and a calibrated eyepiece graticule, selecting only those zircons which showed sharp prismatic edges and in which the most weakly etched tracks, i.e., those parallel to $c$-axis [26], were revealed clearly.

At least two pieces of standard glass, NBS SRM-610 or SRM-612, which had been calibrated against the proposed FT age standard - Fish Canyon Tuff [27] - were wrapped tightly and irradiated with samples. The $\zeta$ values [28] for the

\footnotetext{
${ }^{1} \mathrm{http}: / / \mathrm{www}$. elsevier.nl/locate/epsl; mirror site: http://www. elsevier.com/locate/epsl
} 


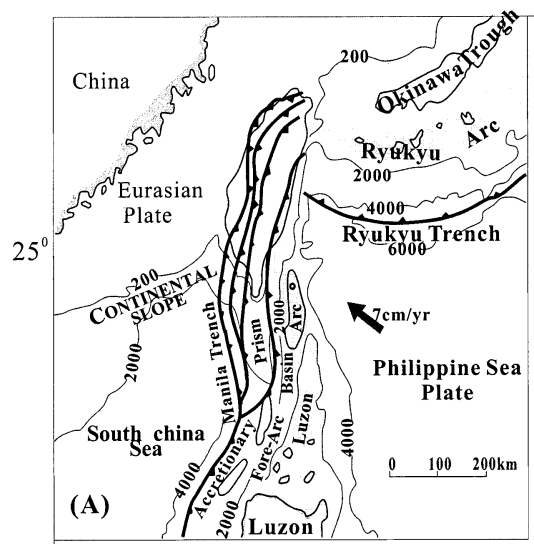

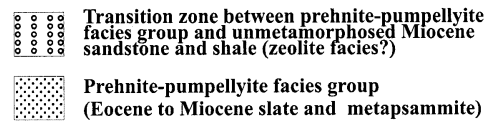

: Greenschsit facies group

: $: \begin{aligned} & \text { Greenschsit facies group } \\ & \text { (Eocene to Miocene slate and metapsammite) }\end{aligned}$

Greenschist facies group and local amphibolite
facies oroup

12 facies group overprinted by greenschist facies

rocks metamorphosed in Mesozoic Era and Plio-
Plist Pleistocene time)

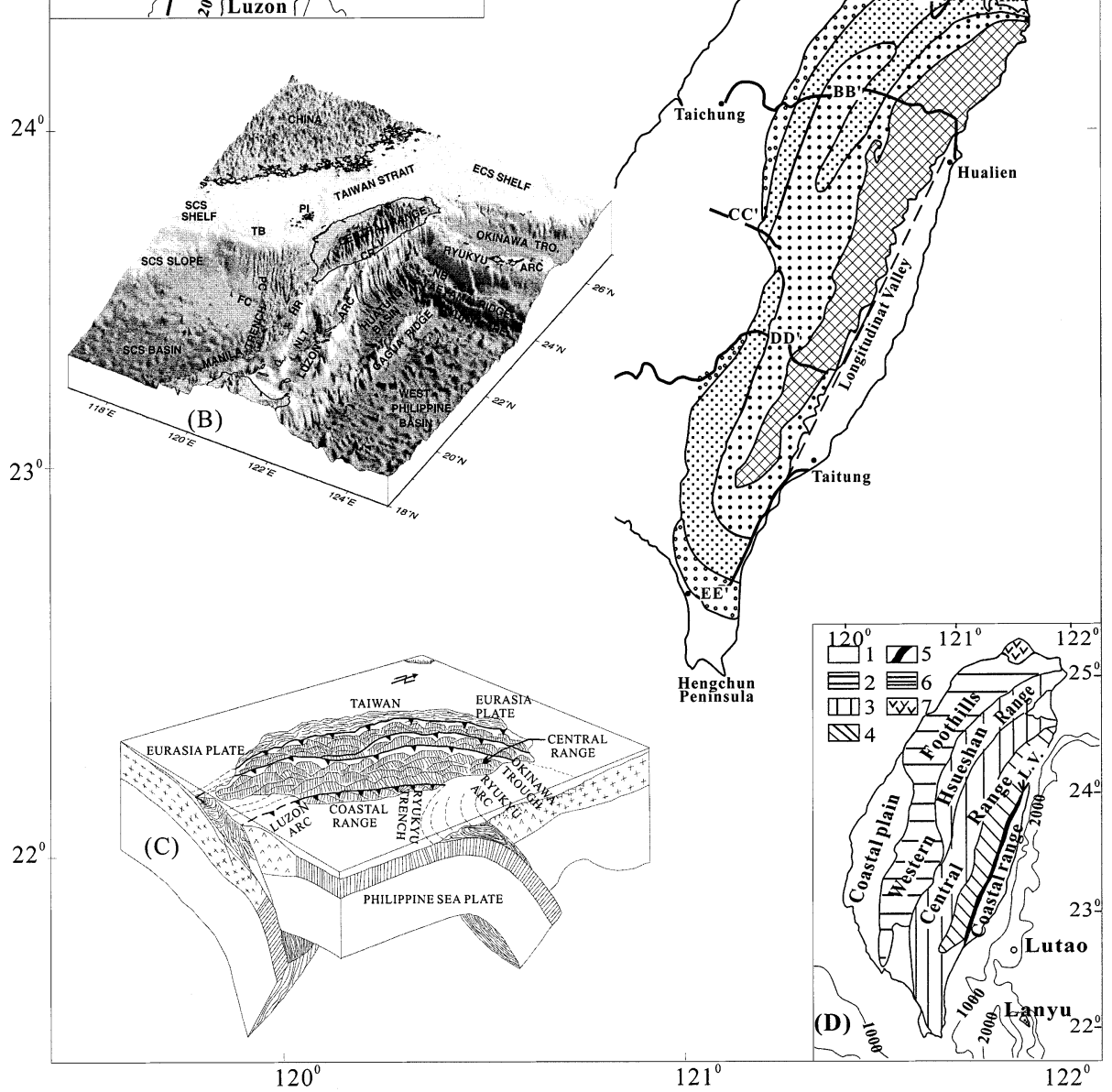

Fig. 1. Metamorphic facies of Taiwan (after [21]) and the six transects (AA'-EE') of sampling. Inset (A) shows the tectonic setting and bathymetry. Inset (B) is the 3-D physiographic diagram of Taiwan and its surrounding area. CR: Coastal Range. ECS: East China Sea. FC: Formosa Canyon. HB: Huatung Basin. HR: Hengchun Ridge. LV: Longitudinal Valley. NB: Nanao Basin. NLT: North Luzon Trough. PC: Penghu Canyon. PI: Penghu Island Group. SCS: South China Sea. TB: Taiwan Banks. Inset (C) is a schematic block diagram showing arc-continent collision and plate tectonic setting (after [22]. Inset (D) shows the generalized geologic and structural units (after [23]): 1= Holocene deposits of the Coastal Plain. 2= Miocene-Pleistocene sediments of the Western Foothills. 3 and $4=$ submetamorphic and metamorphic belt of the Hsueshan Range and the Central Range, respectively. 5= Quaternary deposits of the Longitudinal Valley. 6= Late Cenozoic deposits of the Coastal Range. $7=$ Quaternary volcanic rocks. 
standard glasses SRM-612 and SRM-610 were evaluated to be $340 \pm 12(1 \sigma)$ and $27.5 \pm 1.0(1 \sigma)$, respectively. The former is comparable to the value of $339 \pm 10(2 \sigma)$ by Hurford and Green [28] and $342.1 \pm 6.2(2 \sigma)$ by Tagami [29].

FT grain ages were calculated using the equation:

$T_{\text {unk }}=\left(1 / \lambda_{\mathrm{d}}\right) \ln \left[1+\left(\rho_{\mathrm{s}} / \rho_{\mathrm{i}}\right) \lambda_{\mathrm{d}} \rho_{\mathrm{d}} \zeta\right]$

where $\lambda_{\mathrm{d}}$ is the total decay constant of uranium $\left(1.551 \times 10^{-10} \mathrm{yr}^{-1}\right)$ and $\rho_{\mathrm{d}}$ the detector track density from the standard glass dosimeter (tracks per $\mathrm{cm}^{2}$ ). Uncertainties in ages were calculated from the Poisson uncertainties in $N_{\mathrm{s}}, N_{\mathrm{i}}, N_{\mathrm{d}}$ and $\zeta$ values in the manner described by Green [30]. The final fractional uncertainty in grain age $T$ is:

$$
\begin{aligned}
& \sigma(T) / T=\left\{\left[\frac{\sigma\left(N_{\mathrm{s}}\right)}{N_{\mathrm{s}}}\right]^{2}+\left[\frac{\sigma\left(N_{\mathrm{i}}\right)}{N_{\mathrm{i}}}\right]^{2}+\right. \\
& \left.\left[\frac{\sigma\left(N_{\mathrm{d}}\right)}{N_{\mathrm{d}}}\right]^{2}+\left[\frac{\sigma(\zeta)}{\zeta}\right]^{2}\right\}^{1 / 2}
\end{aligned}
$$

where $N_{\mathrm{s}}$ and $N_{\mathrm{i}}$ denote the number of counts of spontaneous and induced tracks, respectively, in each crystal and $N_{\mathrm{d}}$ is the count induced by the standard glass dosimeter and registered on a mica detector. All sample ages were calculated using the ZetaAge program V4.5 written by Brandon [31].

\section{Results and discussions}

The FT analysis results for the six transects are summarized in six tables and displayed in seven figures (see EPSL Online Background Dataset ${ }^{1}$ for FT data and their graphical presentations). Table 1 is an example, which shows FT data for the western part of the Central Cross-island Highway transect. The youngest and oldest grain ages for individual rock samples are listed in the tables and their differences are used to define the span of each grain age population. For purposes of comparison, the characteristics of the distribution of grain ages for each sample are shown by the radial plot as described by Galbraith [32] and Galbraith and Laslett [33], composite probability density plot, and grain age histogram. Previous FT studies on friable sandstones from the unmetamorphosed pre-Pliocene strata of the Western Foothills Belt confirmed that they were all derived from source rocks in southeast China with zircon FT ages much older than $90 \mathrm{Ma}$ [17]. The spatial pattern of the paleo-temperatures and thermokinematic evolution of the orogen will be investigated by relationships among FT grain age populations, ages of provenance rocks, and depositional ages of sediments.

An important basis in interpreting our FT data is the distinction among unreset (or insignificantly reset), partially reset, and totally reset samples in terms of degree of thermal annealing by the Penglai Orogeny. Among the most useful criteria are the central age and the dispersion (or span) of the FT grain age distribution of each rock sample. A sample was designated 'unreset' if all of its grain ages and central age are much older than its depositional age (i.e., $\gg 90 \mathrm{Ma}$ ) and their span is large. In contrast, a sample was classified as 'totally reset' if its grain ages are much younger than the time of the onset of the Penglai Orogeny (i.e., $\sim 6 \mathrm{Ma}$ in the northern part) and their span is relatively narrow with a unimodal distribution pattern. Between the above-mentioned two categories are the 'partially reset' samples which have an intermediate span of distribution in grain ages (i.e., from 10 to $100 \mathrm{Ma}$ ). It is interesting to note that the unweighted mean of at least 10 grain ages for each rock sample is generally enough to be used as a criterion for distinguishing the three categories of FT annealing. We will examine and discuss the results of each transect in more detail below.

\subsection{Northern Taiwan}

\subsubsection{Hsintien-Ilan (HI-, including the Northern Coast) transect}

Samples W-1 and N-1 were collected from the Oligocene Wuchihshan Formation and Miocene Nanchaung Formation, respectively, in the unmetamorphosed Western Foothills. These two samples confirm the previous conclusion [18] that all zircon grain FT ages of the Tertiary sedimentary rocks in the Western Foothills are older than 90 
Ma and have not been significantly affected by partial resetting after deposition. In contrast, some zircons from the further eastern samples HI-101-105 are apparently younger than their respective depositional ages. But they are still much older than the inferred time of the commencement of the Penglai Orogeny, implying that they have been partially annealed. On the whole, it is clear that the youngest peak ages and central ages for rocks along this transect become progressively younger toward the plate boundary on the south.

\subsubsection{Northern Cross-island Highway (NH-) transect}

Two Eocene samples, NH-203 and 204, and previously published data for sample W-2 from Wulai show the characteristics of completely reset samples: relatively very young central ages $(<10$ $\mathrm{Ma})$, very restricted spans, and almost symmetrical single modes for grain age spectra. The central age for each of the two samples $(6.0 \pm 1.6$ and $6.4 \pm 1.6 \mathrm{Ma}$, respectively) is indistinguishable within error and close to that for sample W-2. The remaining five samples on both sides of the completely reset zone were collected from stratigraphically younger (Oligocene-Miocene) formations, and found to be only partially annealed. Further toward the east, ages in the Tananao Schist have been completely reset and are as young as 1-2 Ma for samples WA-016 and H6188 [17].

Table 1

Zircon FT analytical data for the samples from the western part of the Central Cross-island Highway (CH-) transect

\begin{tabular}{|c|c|c|c|c|c|c|c|c|c|}
\hline \multirow[t]{2}{*}{ Lab\# } & \multirow[t]{2}{*}{ Rock type } & \multirow{2}{*}{$\begin{array}{l}\text { No. of } \\
\text { grains } \\
\text { counted }\end{array}$} & $\begin{array}{l}\rho_{\mathrm{s}} \times 10^{6} \\
\left(\mathrm{~N}_{\mathrm{s}}\right)\end{array}$ & $\begin{array}{l}\rho_{\mathrm{i}} \times 10^{6} \\
\left(\mathrm{~N}_{\mathrm{i}}\right) \\
\end{array}$ & \multirow[t]{2}{*}{$\begin{array}{c}\rho_{\varphi \times 10^{6}} \\
\left(\mathrm{~N}_{\varphi}\right)\end{array}$} & $\begin{array}{c}\text { Grain age } \\
(\mathrm{Ma} \pm 2 \sigma)\end{array}$ & \multirow{2}{*}{$\begin{array}{c}\text { Grain age } \\
\text { span } \\
\text { (Ma) }\end{array}$} & \multirow{2}{*}{$\begin{array}{c}\text { Central age } \\
(\mathrm{Ma} \pm 2 \sigma)\end{array}$} & \multirow{2}{*}{$\begin{array}{c}\begin{array}{c}\chi^{2} \text { age } \\
(\mathrm{Ma})\end{array} \\
\text { Number, and \% of grains }\end{array}$} \\
\hline & & & \multicolumn{2}{|c|}{$\begin{array}{c}\Delta \text { Youngest grain } \\
\nabla \text { Oldest grain }\end{array}$} & & $\begin{array}{l}\text { Youngest grain } \\
\text { Oldest grain }\end{array}$ & & & \\
\hline \multirow{2}{*}{ CH-305 } & \multirow{2}{*}{ meta-sandstone } & \multirow{2}{*}{27} & $\Delta_{(28)}^{\Delta} 1.75$ & $\boldsymbol{\Delta}_{(58)}^{3.63}$ & \multirow{2}{*}{$\begin{array}{l}1.225 \\
(2768)\end{array}$} & $8.2_{-3.3}^{+4.9}$ & \multirow{2}{*}{48.6} & $26.1_{-9.1}^{+13.9}$ & $13.2_{-2.2}^{+2.6}$ \\
\hline & & & $\nabla_{(102)}^{15.3}$ & $\nabla_{(30)}^{4.5}$ & & $56.8_{-19.6}^{+32.8}$ & & $51.2(\%)$ & $8, \quad 30(\%)$ \\
\hline \multirow{2}{*}{$\mathrm{CH}-306$} & \multirow{2}{*}{ slate } & \multirow{2}{*}{17} & $\boldsymbol{\Delta}_{(10)}^{1.13}$ & $\boldsymbol{\Delta}_{(16)}^{1.80}$ & \multirow{2}{*}{$\begin{array}{l}1.225 \\
(2768)\end{array}$} & $10.6_{-6.4}^{+14.2}$ & \multirow{2}{*}{46.0} & $26.9_{-9.6}^{+14.9}$ & $20.8_{-3.6}^{+4.4}$ \\
\hline & & & $\nabla_{(24)}^{6.75}$ & $\nabla_{(7)}^{1.97}$ & & $56.6_{-32.7}^{+101.1}$ & & $40.1(\%)$ & $10, \quad 59(\%)$ \\
\hline \multirow{2}{*}{$\mathrm{CH}-307$} & \multirow{2}{*}{ meta-sandstone } & \multirow{2}{*}{27} & $\boldsymbol{\Delta}_{(6)}^{0.30}$ & $\boldsymbol{\Delta}_{(95)}^{4.75}$ & \multirow{2}{*}{$\begin{array}{l}1.225 \\
(2768)\end{array}$} & $1.1_{-0.7}^{+1.3}$ & \multirow{2}{*}{4.3} & $3.1{ }_{-1.0}^{+1.5}$ & $2.7_{-0.4}^{+0.4}$ \\
\hline & & & $\boldsymbol{\nabla}_{(24)}^{0.76}$ & $\boldsymbol{\nabla}_{(75)}^{2.38}$ & & $5.4_{-2.2}^{+3.3}$ & & $26.5(\%)$ & $20, \quad 74(\%)$ \\
\hline \multirow{2}{*}{ CH-308 } & \multirow{2}{*}{ meta-sandstone } & \multirow{2}{*}{17} & $\boldsymbol{\Delta}_{(28)}^{0.40}$ & $\Delta_{(262)}^{3.73}$ & \multirow{2}{*}{${ }_{(2768)}^{1.225}$} & $1.8_{-0.6}^{+0.9}$ & \multirow{2}{*}{8.2} & $4.3_{-1.5}^{+2.4}$ & $2.9_{-0.5}^{+0.6}$ \\
\hline & & & $\boldsymbol{\nabla}_{(16)}^{2.25}$ & $\boldsymbol{\nabla}_{(27)}^{3.80}$ & & $10.0_{-5.0}^{+9.4}$ & & $38.8(\%)$ & $10, \quad 59(\%)$ \\
\hline \multirow{2}{*}{ CH-309 } & \multirow{2}{*}{ meta-sandstone } & \multirow{2}{*}{28} & $\boldsymbol{\Delta}_{(4)}^{0.23}$ & $\boldsymbol{\Delta}_{(72)}^{4.05}$ & \multirow{2}{*}{${ }_{(2768)}^{1.225}$} & $1.0_{-0.8}^{+1.5}$ & \multirow{2}{*}{4.9} & $2.9_{-1.0}^{+1.4}$ & $2.6_{-0.3}^{+0.4}$ \\
\hline & & & $\nabla_{(16)}^{0.90}$ & $\nabla_{(46)}^{2.59}$ & & $5.9_{-2.8}^{+4.8}$ & & $26.7(\%)$ & $23, \quad 82(\%)$ \\
\hline \multirow{2}{*}{ CH-310 } & \multirow{2}{*}{ meta-sandstone } & \multirow{2}{*}{21} & $\boldsymbol{\Delta}_{(196)} 11.0$ & $\mathbf{\Delta}_{(253)}^{14.2}$ & 1.225 & $13.0_{-2.5}^{+3.2}$ & 117 & $33.7_{-11.5}^{+17.3}$ & $16.2_{-2.4}^{+2.8}$ \\
\hline & & & $\boldsymbol{\nabla}_{(222)}^{7.04}$ & $\boldsymbol{\nabla}_{(68)}^{2.16}$ & & $54.7_{-13.9}^{+19.4}$ & 41.7 & $39.8(\%)$ & $4, \quad 19(\%)$ \\
\hline & & & $\boldsymbol{\Delta}_{(154)}^{4.88}$ & $\mathbf{\Delta}_{(83)} 2.63$ & 1225 & $31.2_{-7.9}^{+10.7}$ & & $60.6_{-20.3}^{+30.5}$ & $43.3_{-6.5}^{+7.6}$ \\
\hline CH-311 & meta-sandstone & 17 & $\nabla_{(114)}^{16.0}$ & $\boldsymbol{\nabla}_{(18)}^{2.53}$ & (2768) & $105.0_{-41.45}^{+80.5}$ & 73.8 & $29.1(\%)$ & $7,41(\%)$ \\
\hline
\end{tabular}

$\rho_{\mathrm{s}}=$ spontaneous FT density $\left(\right.$ tracks $\left./ \mathrm{cm}^{2}\right) . \quad N_{\mathrm{s}}=$ spontaneous FT counted. $\rho_{\mathrm{i}}=$ induced FT density. $N_{\mathrm{i}}=$ sample FT counted. $\rho_{\Phi}=$ FT density induced by NBS glass dosimeter. $N_{\Phi}=$ induced FT counted. All analyses were performed by the external detector $(2 \pi)$ method. Grain age span=oldest grain age minus youngest grain age. Age dispersion = relative standard error of the single grain ages defined by Galbraith and Laslett [33]. The $\chi^{2}$ age was defined by Brandon and Vance [35]. 


\subsubsection{Fushin area (Western Foothills Belt)}

The cooling rate of the northern part of the Western Foothills Belt can be estimated from apatite and zircon FT ages from the Fushin area (T.C. Li, personal communication, 1992). Two apatite concentrates (FS-01 and 02) were separated from an intrusive diabase and two zircon concentrates (FS-03 and 04) from its neighboring sandstone of the unmetamorphosed Miocene Mushan Formation. Zircons of sample FS-04 which is $2 \mathrm{~m}$ apart from the contact were only partially reset as shown by the characteristics of grain age distribution. In contrast, zircons separated from sample FS-03 immediately in contact with the diabase were completely reset with a central age of $18.9 \pm 4.3 \mathrm{Ma}$. This date is much older than the onset of the Penglai Orogeny and is regarded as the time of the diabase intrusion. Two apatite pooled ages, $2.1 \pm 0.3$ and $2.3 \pm 0.3 \mathrm{Ma}$, are essentially equal. Because the diabase body is small and was presumably cooled down to its ambient temperature soon after its intrusion, those two apatite ages also represent the cooling ages of the sample location. With the blocking temperature of $135^{\circ} \mathrm{C}$ for apatite, the presentday average ground temperature of $15^{\circ} \mathrm{C}$, and the thermal gradient of $30^{\circ} \mathrm{C} / \mathrm{km}$ measured, the cooling rate estimated for the Western Foothills [34] was $\sim 60^{\circ} \mathrm{C} / \mathrm{Ma}$, which is much lower than that of the backbone Central Range $\left(\sim 220^{\circ} \mathrm{C} /\right.$ $\mathrm{Ma})$ estimated from mean apatite FT ages of 0.4 Ma [17].

\subsection{Central Taiwan}

\subsubsection{Central Cross-island Highway ( $\mathrm{CH}-)$ and middle Taiwan (MT-) transects}

Along the Central Cross-island Highway transect, the completely reset zone is divided into two parts by the partially reset Miocene Lushan Formation (CH-305 and 306) (Table 1), the western one of which is the southern extension of the totally reset Eocene formation mentioned above. Immediately to both sides of the Lushan Formation are the stratigraphically older Eocene strata. Thus, the degree of annealing is closely related to the stratigraphic level and to a lesser extent to local geothermal relief high. The younger a for- mation is, the less the degree of annealing. In other words, the maximum thermal overprint on the mountain belt occurred prior to the crustal deformation that produced the present-day geological and structural configurations.

Three rock samples (MT-401-403) were collected from the New Central Highway in central Taiwan. The eastern two of them have fairly symmetrical single-mode age spectra with $\chi^{2}$ ages [35] of $2.4 \pm 0.5$ and $3.3 \pm 0.6 \mathrm{Ma}$, respectively, indicating that both were completely reset by the Penglai Orogeny and that the eastern one is younger. The third one, MT-403 on the west, has been only partially reset as demonstrated by its distinct multi-peaks of the composite probability density curve, $\chi^{2}$ age of 19.7 Ma (which is apparently older than the initiation of the orogeny), and the wide span (62.4 Ma) of grain ages. Apparently, the surface boundary between the totally and the partially reset zones exists somewhere between the two sampling localities.

\subsection{Southern Taiwan}

\subsubsection{Southern Cross-island Highway ( $\mathrm{SH}-$ ) and Southern Round-island Highway (SR-) transects}

The distribution spectra of grain and central ages for individual rock samples from $\mathrm{SH}$ and SR transects shift toward the younger direction and at the same time their spans become tighter as the distances between sample outcrops and the Longitudinal Valley decrease. Four samples (SH501-504) from the southern end of the Tananao Schist have similar cooling ages $(0.9-2.4 \mathrm{Ma})$ as those for the Yuantoushan gneiss from the Nanao area in the northern part of the Tananao Schist Belt. It is also noteworthy that those ages are much younger than those of the neighboring completely reset sample SR-601 $(\sim 6.0 \mathrm{Ma})$ from the eastern part of the SR transect. This sample was collected from a Miocene formation unformably overlying the schist and is situated within the domain of greenschist facies. It is interpreted as totally reset because it meets the criteria of reset mentioned above and passes the $\chi^{2}$ test, indicating that a single population is present at this site. Moreover, the sample contains quartz veinlets in 
shear zones, which is characteristic of rocks subjected to a temperature of $\geq 260^{\circ} \mathrm{C}[36]$. Assuming a geothermal gradient of $42^{\circ} \mathrm{C} / \mathrm{km}$ estimated from the interpolation of $55^{\circ} \mathrm{C} / \mathrm{km}$ [37] and $30^{\circ} \mathrm{C} / \mathrm{km}$ [34] for geothermal wells in the schist area and the Western Foothills, respectively, the cooling rate estimated for $\mathrm{SR}-601$ is $\sim 41^{\circ} \mathrm{C} / \mathrm{Ma}$, which corresponds to an uplift rate of $1.0 \mathrm{~mm} / \mathrm{yr}$.

The area along the SR transect is not farther away from the plate boundary than is the area of the southern end of the Tananao Schist (SH-501504). However, there is a marked difference in

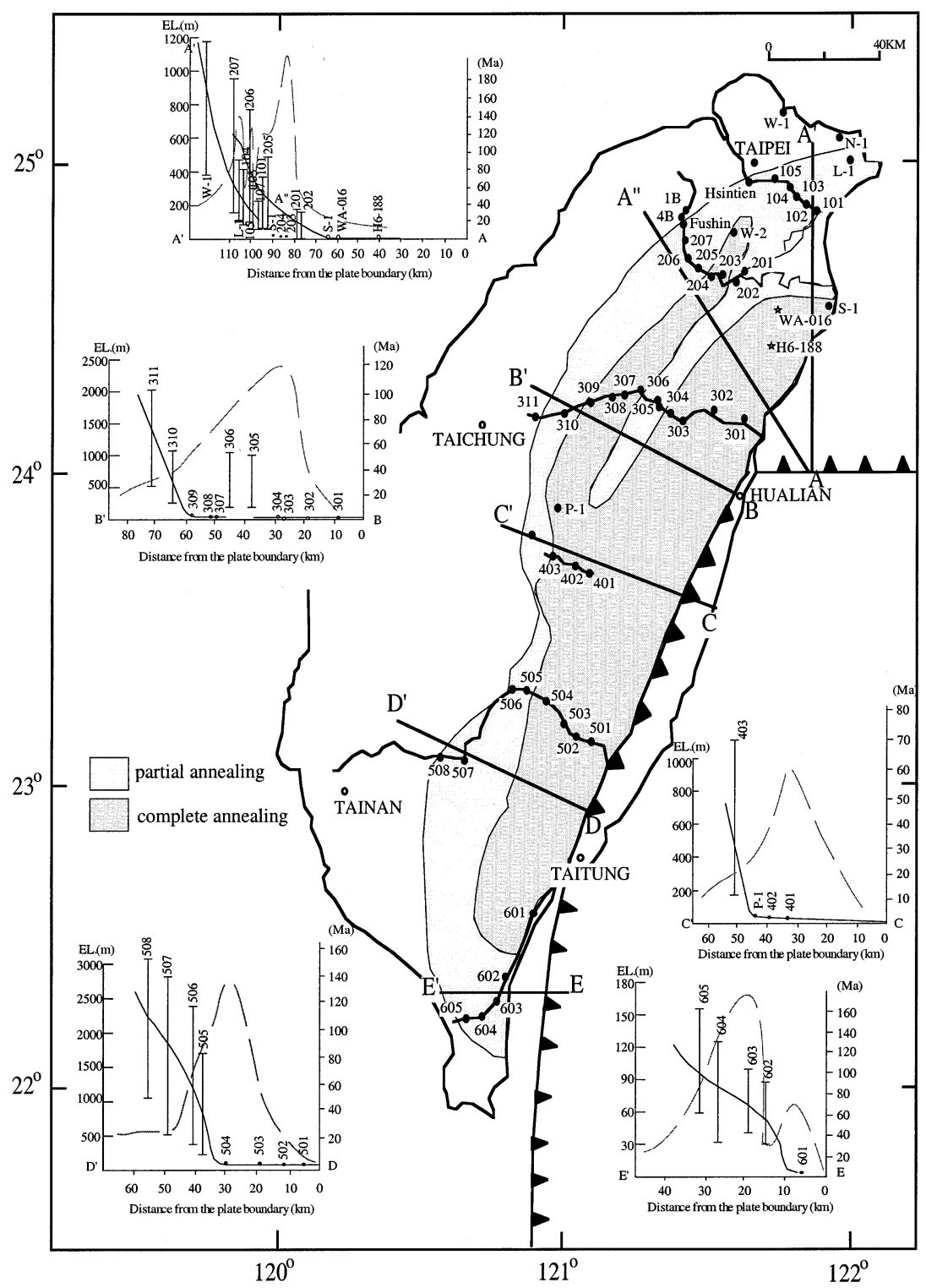

Fig. 2. The spatial pattern of zircon grain ages and the degree of FT annealing. The six insets are the graphical representation of the measured zircon FT ages and the sample elevation (dashed lines) along the six profiles ( $\mathrm{AA}^{\prime}$ to $\left.\mathrm{EE}^{\prime}\right)$. The bars indicate the span of zircon grain ages for each sample. 
completely reset zircon ages between the two areas. This draws our attention to the fact that the Tananao Schist juxtaposes with the collisionformed Coastal Range while the SR area does not. Therefore, the much lower uplift-and-cooling rate of the SR area, as implied by the distinctly older FT ages, might be explained by its still being situated to the further south of the head-on collision zone.

\subsection{Comparison of the degree of zircon FT annealing with metamorphic facies}

By comparing Fig. 1 with Fig. 2, we demonstrate that the boundary between the partially and totally reset zones coincides very well with that between the prehnite-pumpellite and the greenschist facies previously defined by Chen et al. [21] with crystallinity of K-micas. The only exception occurs in the Wulai-Suleng area (samples W-2, NH-203 and 204), because no sample was collected from that area in the above-stated crystallinity study and its metamorphic facies was underestimated. According to Hoffman and Hower [38], the transformation of illite/smectite within the prehnite-pumpellite facies to $2 \mathrm{M}$ mica within the greenschist facies occurs at about $260^{\circ} \mathrm{C}$. Therefore, for the rapid cooling rates implied by the young zircon FT ages (3-6 Ma), the FT closure temperature for zircons from the mountain belt is suggested to be $260 \pm 20^{\circ} \mathrm{C}$, instead of the previous estimation $\left(235 \pm 20^{\circ} \mathrm{C}\right)$ [17].

\subsection{East-west cross-sectional profile of uplift-and-cooling}

The Taiwan mountain belt is well known to be a typical compressional wedge [13]. According to a steady-state kinematic wedge model previously developed by Dahlen and Suppe [14], the $P-T-t$ path for a rock traveling through the wedge varies as a function of distance from the toe (the deformation front) of the wedge. A rock which outcrops farther away from the deformation front experienced deeper burial and higher temperatures than the rocks exposed at localities close to the front [19]. The spatial pattern of the degree of zircon FT annealing for each transect of this

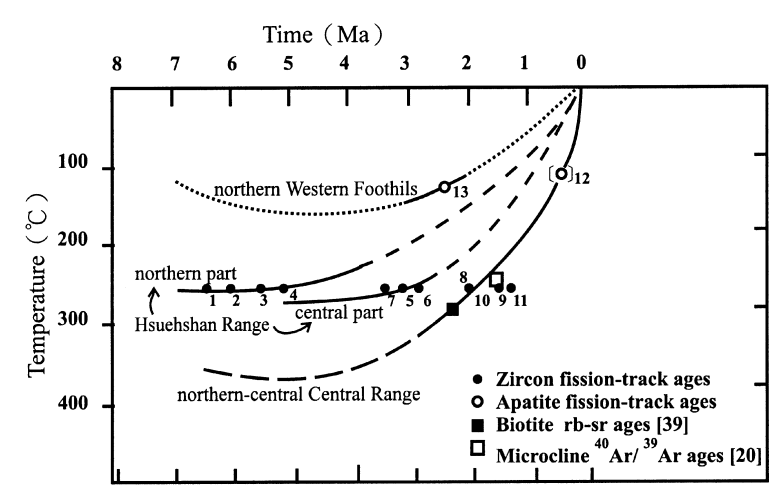

Fig. 3. Cooling history of the three geological units in northern Taiwan, from west to east the Western Foothills, the Hsueshan Range and the Central Range, since the Penglai Orogeny reconstructed by combining different temporal-thermal systematics. Biotite Rb-Sr from [39]

study supports that model. From the Western Foothills Belt toward the Central Range, the FT ages of zircon and apatite become younger and younger. Based on the present and previously published data [17,18], cooling histories for the three juxtaposing provinces in northern Taiwan - the Western Foothills Belt, the Hsueshan Range and the Central Range - are schematically delineated in Fig. 3. In this figure, cooling curves for the Central Range and Western Foothills prior to the biotite $\mathrm{Rb} / \mathrm{Sr}$ age of ca. $3 \mathrm{Ma}$ and the apatite FT age of ca. 2.5 Ma can be inferred from the cooling curve for the Hsueshan Range [18]. On the other hand, the cooling curve of the Hsueshan Range since the time of its peak temperature (ca. $6 \mathrm{Ma}$ ) can be determined by interpolating those for the Central Range and Western Foothills Belt. Apparently, the uplift-and-cooling rates progressively increase from the western deformation front toward the rear part of the eastern accretionary wedge.

The topography as well as the distribution of zircon FT central ages of the mountain belt are asymmetrical in the east-west profiles (Fig. 2). The eastern flank (i.e., the Tananao Schist Belt) to the east of the main water divide is much narrower in spatial width and younger in reset FT ages than the Slate Belt and the Western Foothills to the west. It is also noteworthy that the main water divide is mostly situated within the Slate 
Belt and almost coincides with the boundary between the Tananao Schist Belt and the Slate Belt. In other words, the rear (eastern) flank of the mountain belt is steeper in topographic gradients and higher in exhumation and cooling rates than the frontal (western) flank.

\subsection{North-south propagation of peak temperature and subsequent cooling}

Generally, the outcrop rocks of the Taiwan Orogen become stratigraphically older toward the north. In other words, the time of emergence above sea level is earlier and the amounts of total uplift and denudation are larger towards the north. The width of the completely reset zircon zone is about $80 \mathrm{~km}$ in the $\mathrm{NH}$ transect, gradually narrows down and finally pinches out toward the $\mathrm{SR}$ transect. The accretionary wedge from northern Luzon to southern Taiwan becomes wider and higher (Fig. 1). The Hengchun Peninsula at the southern end of the island represents the backbone part of the accretionary fore-arc ridge above sea level. Toward the north, it transforms into the collisional part of the orogen.

Cooling ages for the samples collected from the lower temperature margin of a completely reset terrain in a continuous thermal profile can be regarded as the time of peak temperature attained during the last phase of a thermal event [25]. From north to south, the zircon FT ages of the western margin of the completely reset zone are $6.4 \pm 1.1 \mathrm{Ma}(\mathrm{NH}-204), 5.4 \pm 2.4(\mathrm{~W}-2), 2.9 \pm 0.7$ Ma (CH-309), $3.3 \pm 0.9$ Ma (MT-402), $2.0 \pm 0.5$ Ma (SH-504), 6.0 \pm 1.3 Ma (SR-601; Fig. 4). The distance and age differences between the $\mathrm{NH}$ and $\mathrm{SH}$ transects were about $200 \mathrm{~km}$ and $4 \mathrm{Myr}$, respectively. Therefore, the average rate of southward propagation of the peak temperature is estimated to be about $50 \mathrm{~km} / \mathrm{Ma}$.

\subsection{Important role of the Peikang Basement High in 'salient-and-recess' structural trend and neotectonic movements}

The much younger zircon FT ages for the westcentral margin of the completely reset zone (Fig. 4) indicate that the central part of the mountain belt, roughly between the $\mathrm{CH}$ transect and the $\mathrm{SH}$ transect, has much faster uplift rates than its northern and southern sides. From the regional point of view, the structural trend of the Western Foothills Belt and the Hsueshan Range shows a stretched S shape of a typical 'salient-and-recess' structure. In a sense, this structure was inherited from the outline shape of the pre-Tertiary continental margin as manifested by the two pre-Tertiary basement highs shown in the north-south stratigraphic profile of western Taiwan. The major one was called the Peikang High, which was first encountered in the borehole at Peikang and then confirmed to exist under the west central part of the Taiwan island to the off-shore Penghu Islands [40]. Another one is the minor Kuanying High, which underlies the northwestern offshore area. Due to the northwestward compression of the Coastal Range on the western edge of the Philippine Sea Plate, the overlying weak Tertiary sediments between the two basement highs were pushed further to the west, resulting in a salient. In contrast, the compression was obstructed by the two highs, especially the Peikang High. Accordingly, the trend of folds and faults surrounding the Peikang High has been indented and concave toward the east, resulting in the recess. The greater compression undertaken by the recess portion can account for not only the markedly larger uplift-and-cooling rates mentioned above but also the reason why the highest peak on the island, Mt. Yushan, occurs at the central part of the recess structure.

Seismicity in Taiwan can be divided into two zones (Fig. 4). The eastern zone is directly related to plate subduction, including the eastward subduction of the Eurasian Plate along the Longitudinal Valley and its southern extension, and the northward subduction of the Philippine Sea Plate along the Ryukyu Trench. However, the western seismic zone, which includes the recent disastrous Chi-Chi earthquake $\left(M_{\mathrm{L}}=7.3 ; 21\right.$ September 1999) [41] and its aftershocks, is related to westward thrusting and distributed along the curvature of the recess of the Western Foothills Belt. The existence and influence of the Peikang High are also reflected in the direction of GPS station velocities (Fig. 4) [42]: the northern and southern 


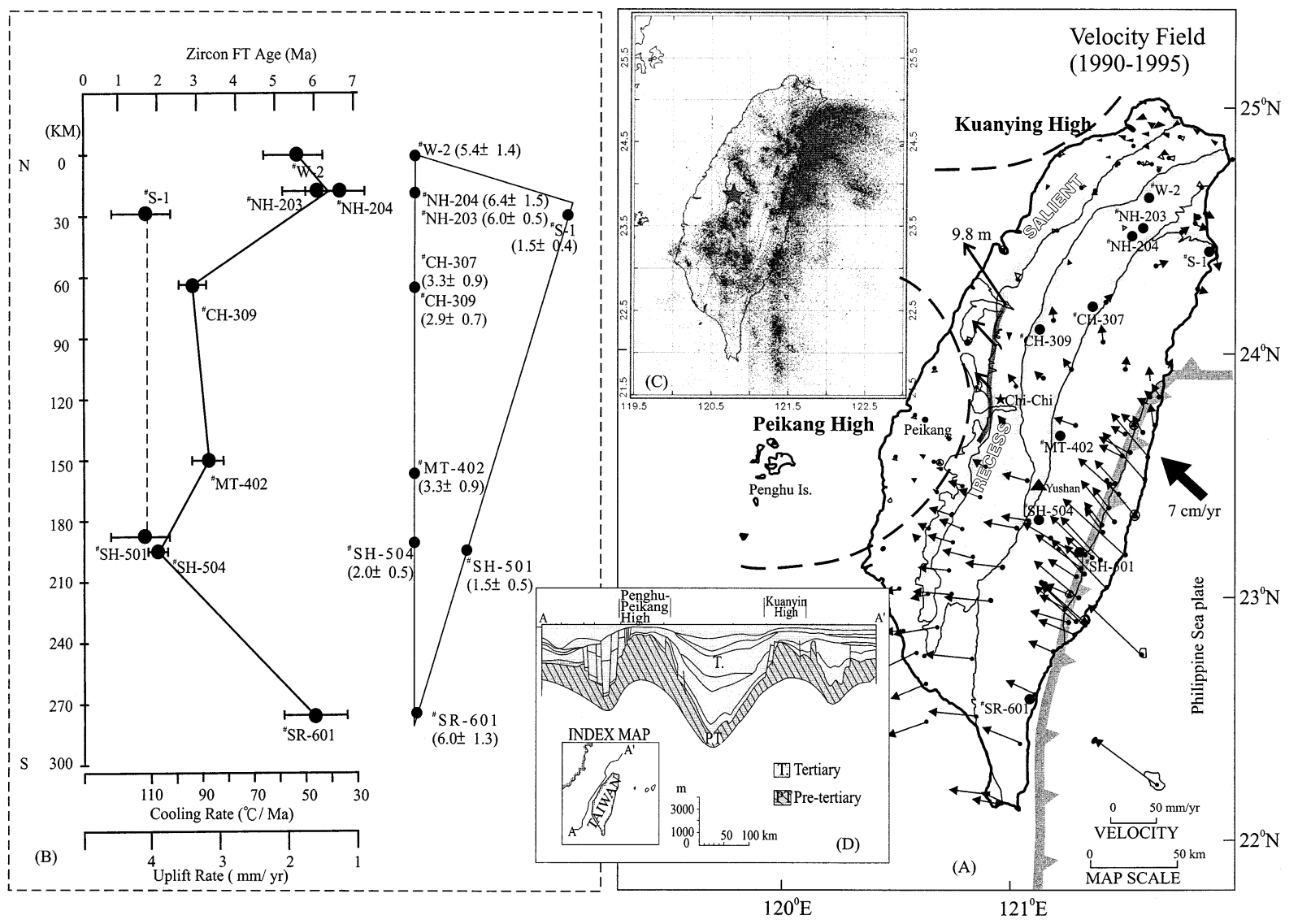

Fig. 4. Comparison of (A) the velocity vectors (denoted by arrows) of GPS stations relative to Penghu Island (after [42]) and (B) the corresponding FT ages and cooling-and-uplift rates of the western margin of the zircon completely reset zone shown in Fig. 2. Each triangle without a line connecting to a dot represents negligible horizontal displacement. Inset (C) is the seismicity in the Taiwan region over the past 100 years [43]. The dark curve to the west of the epicenter of the Chi-Chi earthquake is the Chelungpu fault, which induced the earthquake. The three arrows stemming from the fault represent coseismic horizontal displacement. Inset (D) shows the NE-SW longitudinal geologic section of the Cenozoic basins in offshore Taiwan (modified from [40]). The three broad gray lines delineate the structural trend of the island. The role of the Peikang Basement High in forming the recess structure and influencing the crustal movements is clearly shown.

flanks of the recess have been deviating from their supposedly original northwestward direction to northward and westward directions, respectively.

\section{Conclusions}

1. The pre-Penglai Orogeny FTs in detrital zircon and apatite of the Central Range were subjected to varying degrees of annealing by the heating of the Penglai Orogeny. As the degree of annealing increases toward the east, central ages become younger and their grain age distribution span (or dispersion) becomes narrower. A mineral species was considered to have been totally reset if the central age, with a dispersion of $<40 \%$, of clastic grains is much younger than the commencement of the Penglai Orogeny.

2. The spatial boundary between the total and partial resetting of zircons from the mountain belt of Taiwan coincides well with that between the low greenschist facies and prehnite-pumpellite facies defined by the transformation of 
illite/smectite to $2 \mathrm{M}$ mica. That boundary corresponds to the FT closure temperature for zircons $\left(\sim 260^{\circ} \mathrm{C}\right)$ in the mountain belt.

3. The width of the zircon totally reset zone gradually narrows toward the south. Besides, zircon FT central ages for the margin of the totally reset zone become progressively younger from 5-6 $\mathrm{Ma}$ in the northwestern part to 1-2 $\mathrm{Ma}$ in the south-central part, and return to ca. $6 \mathrm{Ma}$ further south. The spatial and temporal patterns of these cooling ages reflect the southward propagation $(\sim 50 \mathrm{~km} / \mathrm{Ma})$ of the arccontinent collision and subsequent uplift-anddenudation.

4. The mountain belt of Taiwan acquired its present salient-and-recess structural trend by inheriting irregularity of pre-Tertiary tectonized continent margin. The uplift-and-cooling rates of the mountain belt increase from the deformation front toward the plate boundary (the Longitudinal Valley). The ages of fully reset samples, especially sample SR-601 to the south of the valley, demonstrate that the same rates of the recess segment are much higher than those of the northern and southern parts due to the obstruction of the Peikang Basement High under west central Taiwan. Thus, the Basement High plays an important role in the thermo-kinematic evolution as well as neotectonics of the mountain belt.

\section{Acknowledgements}

The authors are grateful to Dr. Yuan Wang for greatly polishing the early version of the manuscript. Critical reviews and comments by Drs. Sean D. Willett and Stephane Guillot helped improve the presentation and focus of this paper. We are indebted to Dr. Shiang-Huei Jiang for helping us with neutron irradiation at National Tsing Hua University, Taiwan. Thanks are also due to Miss Nan Chou and Miss Pei-Wen Peng for assistance in data processing, typing, and drawing. This study was financed by the National Science Council of the Republic of China under Grant NSC-72-0202-M002-03.[FA]

\section{References}

[1] U. Haack, The closing temperature for fission track retention in minerals, Am. J. Sci. 277 (1977) 459-464.

[2] P.E. Zaun, G.A. Wagner, Fission-track stability in zircons under geological conditions, Nucl. Tracks 10 (1985) 303307.

[3] A.J. Hurford, F.J. Fitch, A. Clark, Resolution of the age structure of the detrital zircon populations of two Lower Cretaceous sandstones from the Weald of England by fission track dating, Geol. Mag. 121 (1984) 269-277.

[4] B.J. Kowallis, J.S. Heaton, K. Bringhurt, Fission-track dating of volcanically derived sedimentary rocks, Geology 14 (1986) 19-22.

[5] D. Seward, D.A. Rhoades, A clustering technique for fission track dating of fully to partially annealed minerals and other non-unique populations, Nucl. Track Radiat. Meas. 11 (1986) 259-268.

[6] A.J. Hurford, Cooling and uplift patterns in the Lepontine Alps, South Central Switzerland and an age of vertical movement on the Insubric fault line, Contrib. Mineral. Petrol. 92 (1986) 413-427.

[7] S.V. Roberts, D.W. Burbank, Uplift and thermal history of the Teton Range (northwestern Wyoming) defined by apatite fission-track dating, Earth Planet. Sci. Lett. 118 (1993) 295-309.

[8] P.A.M. Andriesen, H.P. Zeck, Fission-track constraints on timing of Alpine nappe emplacement and rates of cooling and exhumation, Torrox area, Betic Cordilleras, S. Spain, Chem. Geol. 131 (1996) 199-206.

[9] M.T. Brandon, M.K. Roden-Tice, J.I. Garver, Late Cenozoic exhumation of the Cascadia accretionary wedge in the Olympic Mountains, Northwest Washington State, Geol. Soc. Am. Bull. 110 (1998) 985-1009.

[10] C. Biq, Dual-trench structure in the Taiwan-Luzon region, Proc. Geol. Soc. China 15 (1972) 65-75.

[11] C. Biq, Kinematic pattern of Taiwan as an example of actual continent-arc collision, in: Report of the Seminar on Seismology, US-ROC Cooperative Science Program, 1973, pp. 21-26.

[12] J. Suppe, Mechanics of mountain building in Taiwan, Mem. Geol. Soc. China 4 (1981) 67-89.

[13] J. Suppe, Kinematics of arc-continent collision, flipping of subduction, and back-arc spreading near Taiwan, Mem. Geol. Soc. China 6 (1984) 21-33.

[14] F.A. Dahlen, J. Suppe, Mechanics, growth, and erosion of mountain belts, in: S.P. Clerk (Ed.), Processes in Continental Lithospheric Deformation, Geol. Soc. Am. Spec. Pap. 218 (1988) 161-178.

[15] L.S. Teng, Geotectonic evolution of late Cenozoic arccontinent collision in Taiwan, Tectonophysics 183 (1990) 57-76.

[16] C.Y. Huang, W.Y. Wu, C.P. Chang, S. Tsao, P.B. Yuan, C.W. Lin, X.K. Yuan, Tectonic evolution of accretionary prism in the arc-continent collision terrane of Taiwan, Tectonophysics 281 (1997) 31-51. 
[17] T.K. Liu, Tectonic implication of fission track ages from the Central Range, Taiwan, Proc. Geol. Soc. China 25 (1982) 22-37.

[18] T.K. Liu, Fission track dating of the Hsueshan Range: Thermal record due to arc-continent collision in Taiwan, Acta Geol. Taiwan 26 (1988) 279-290.

[19] T.D. Barr, F.A. Dahlen, Brittle frictional mountain building 2: Thermal structure and heat budget, J. Geophys. Res. 94 (1989) 3923-3947.

[20] C.H. Lo, T.C. Onstott, Rejuvenation of K-Ar systems for minerals in the Taiwan mountain belt, Earth Planet. Sci. Lett. 131 (1995) 71-98.

[21] C.-H. Chen, H.T. Chu, J.G. Liou, W.G. Ernst, Explanatory notes for the metamorphic facies map of Taiwan, Contrib. Geol. Surv. Taiwan, Spec. Publ. 2 (1983) 32.

[22] J. Angelier, Preface, Geodynamics of the Eurasia-Phillippine Sea plate boundary, Tectonophysics 125 (1986) IX$\mathrm{X}$.

[23] C.S. Ho, A synthesis of the geologic evolution of Taiwan, Tectonophysics 125 (1986) 1-16.

[24] G.A. Wagner, G.M. Reimer, Fission track tectonics: the tectonic interpretation of fission track apatite age, Earth Planet. Sci. Lett. 14 (1972) 263-268.

[25] T.K. Liu, Y.G. Chen, W.S. Chen, S.H. Jiang, Rates of cooling and denudation of the early Penglai Orogeny, Taiwan assessed by fission-track constraints, Tectonophysics 320 (2000) 69-82.

[26] A.J.W. Gleadow, Fission-track dating methods: what are the real alternatives?, Nucl. Tracks 5 (1981) 3-14.

[27] C.W. Naeser, R.A. Zimmermann, G.T. Cebula, Fission track dating of apatite and zircon: an interlaboratory comparison, Nucl. Tracks 5 (1981) 65-72.

[28] A.J. Hurford, P.F. Green, The zeta calibration of fission track dating, Isotope Geosci. 1 (1983) 285-317.

[29] T. Tagami, Determination of zeta calibration constant for fission track dating, Nucl. Tracks Radiat. Meas. 13 (1987) 127-130.

[30] P.F. Green, A new look at statistics in fission-track dating, Nucl. Tracks 5 (1981) 77-86.

[31] M.T. Brandon, Probability density plot for fission-track grain-age samples, Radiat. Meas. 26 (1996) 663-676.

[32] R.F. Galbraith, The radial plot: graphical assessment of spread in ages, Nucl. Tracks Radiat. Meas. 17 (1990) 207 214.

[33] R.F. Galbraith, G.M. Laslett, Statistical models for mixed fission track ages, Nucl. Tracks Radiat. Meas. 21 (1993) 459-470.

[34] J. Suppe, J.H. Witte, Abnormal pore-fluid pressures in relation to stratigraph and structure in the active foldand-thrust belt of northwestern Taiwan, Petrol. Geol. Taiwan 14 (1977) 11-24.

[35] M.T. Brandon, J.A. Vance, Tectonic evolution of the Cenozoic Olympic subduction complex, Washington State, as deduced from fission track ages for detrital zircons, Am. J. Sci. 292 (1992) 565-636.

[36] L.P. Teng, C. Wang-Lee, Quartzites and quartz veins, Acta Geol. Taiwan. 19 (1977) 74-78.

[37] C.R. Lee, W.T. Cheng, Preliminary heat flow measurements in Taiwan, in: Proceedings of the 4th Circum-Pacific Energy and Mineral Resources Conference, Singapore, 1986.

[38] J. Hoffman, J. Hower, Clay mineral assemblage as low grade metamorphic geothermometers: Application to the thrust faulted disturbed belt of Montana, USA, in: P.A. Scholle, P.R. Schluger (Eds.), Aspects of Diagenesis, Soc. Econ. Paleontol. Mineral. Spec. Publ. 26 (1979) 5580.

[39] B.M. Jahn, F. Martineau, J.J. Peuca, J. Cornichet, Geochronology of the Tananao Schist complex and crustal evolution of Taiwan, Mem. Geol. Soc. China 7 (1986) 383-4041.

[40] S.C. Sun, Y.Y. Hsu, Overview of the Cenozoic geology and tectonic development of offshore and onshore Taiwan, in: Taicrust Workshop Proceedings, 1991, pp. 3547.

[41] K.F. Ma, C.T. Lee, Y.B. Tsai, The Chi-Chi, Taiwan earthquake: Large surface displacements on an inland thrust fault, EOS 80 (1999) 50.

[42] S.B. Yu, H.Y. Chen, L.C. Kua, Velocity fields of GPS stations in the Taiwan area, Tectonophysics 274 (1997) 41-59.

[43] C.Y. Wang, C.H. Chang, H.Y. Yen, An interpretation of the 1999 Chi-Chi earthquake in Taiwan based on the thinskinned thrust model, TAO 11 (2000) 609-630. 